\title{
Cigarette smoking patterns during the working day
}

\author{
T. W. MEADE AND N. J. WALD*
}

MRC-DHSS Epidemiology and Medical Care Unit, Northwick Park Hospital, Harrow, Middlesex

SUMMARY The rates at which people smoke cigarettes during different periods of the day were obtained from three occupational groups. Group 1 consisted of those working at the main London production site of a food processing factory, Group 2 consisted of those in the administrative offices of the same company; there are smoking restrictions at both. Group 3 consisted of workers in the offices of a London borough where there are no smoking restrictions. Replies were received from 3174 people, or $88 \%$ of those approached. There was a higher proportion of non-smokers (over $70 \%$ ) among the two groups of office workers than among the food processing workers (about $55 \%$ ). Smokers in Group 3 recorded somewhat higher average cigarette consumption than those in Groups 1 and 2. During different periods of the day, the maximum hourly rate of cigarette smoking was about three times the minimum rate. For Groups 1 and 2 the maximum rate was consistently during the interval between leaving work and going to bed. In contrast, the maximum rate for Group 3 was consistently during the afternoon, while at work, and the rate between leaving work and going to bed was similar to the rate for the day as a whole. Results will help in deciding the time of day at which blood for carboxyhaemoglobin estimations should be taken.

While much is known about the total daily quantities of cigarettes and other forms of tobacco smoked, little if any information is available about cigarette consumption during different periods of the day; these details are needed for studies on smoking related to blood carboxyhaemoglobin ( $\mathrm{COHb})$ estimations, since $\mathrm{COHb}$ levels in tobacco smokers vary throughout the day and are affected by the pattern of tobacco consumption (Wald and Howard, 1975; Wald et al., 1975). Depending on the extent of inhalation, and the type and brand of tobacco, variable amounts of carbon monoxide are drawn into the lungs during smoking. Carbon monoxide is over 200 times more readily bound to haemoglobin than oxygen, and since accurate and practicable methods for measuring $\mathrm{COHb}$ levels are available, these levels may give more valid and objective indications of the extent to which the gaseous phase of tobacco smoke reaches the lungs than self-reported information on levels of inhalation. Those with high $\mathrm{COHb}$ levels may be expected subsequently to experience a higher incidence of certain smoking-related diseases than those with low levels; in this sense, $\mathrm{COHb}$ levels may provide a general 'marker' for those at varying risks of these diseases. In addition, the possibility that carbon

*Present address: DHSS Cancer Epidemiology and Clinical Trials Unit, Department of the Regius Professor of Medicine, Radcliffe Infirmary, Oxford. monoxide is specifically related to the production of atheroma (Astrup, 1972) suggests that $\mathrm{COHb}$ determinations may help to clarify the role of smoking in the onset of ischaemic heart disease, a condition in which the role of smoking is less clear than in lung cancer. Wald et al. (1973), in a crosssectional study, found that those with $\mathrm{COHb}$ levels of $5 \%$ or more were 21 times more likely to have had episodes of clinical arterial disease than those of the same age and sex with similar past and present smoking habits, but with $\mathrm{COHb}$ levels of less than $3 \%$.

Blood carbon monoxide has a half-life of less than four hours (varying under different circumstancesfor example, with exercise). $\mathrm{COHb}$ levels measured early in the day may therefore only approximately reflect habitual day-time $\mathrm{COHb}$ levels, since they will be disproportionately influenced by the shortterm effects of the relatively small amount of tobacco smoked during the first few hours after waking. Information on rates at which tobacco (especially in cigarettes) is smoked during different periods of the day is thus important.

\section{Methods}

Between 1972 and 1974, a standard questionnaire was sent to three groups of employees. Group 1 
consisted of those working at the main London production site of a food processing factory, and Group 2 consisted of those at the company's head office. Most of those in Group 1 were manual workers while those in Group 2 were mainly administrative office workers, although some manual and office workers were represented in each group. Smoking restrictions are in force at both the factory and the head office where smoking is allowed only in specially designated areas and in the canteens; it is not allowed on the production lines, during maintenance and similar activities, or in offices. There are fewer opportunities to smoke for Group 1 than Group 2 because of the difficulties of leaving production lines. Group 3, comprising members of the administrative and legal departments of a London borough, was included to provide information where no smoking restrictions are in operation. Employees in Group 3 were similar to those of Group 2 in terms of social class, type of work, proportions of managerial, clerical, and other grades, and area of residence.

In the questionnaire, participants were asked to classify themselves according to their current cigarette smoking habits as either smokers (at least one cigarette each day) or non-smokers. No further details were sought from non-smokers, ex-smokers, or from current cigar and pipe smokers. Current cigarette smokers (now described as 'smokers') were then asked to record the number of cigarettes smoked:

(a) from rising until arrival at work;

(b) from arrival at work until the end of the morning tea or coffee break;

(c) from the end of the morning break until the end of the lunch break;

(d) from the end of the lunch break until the end of the afternoon tea break; (e) from the end of the afternoon tea break until departure from work;

(f) from departure from work until going to bed; and

(g) in total; each person was asked to check that the overall numbers of cigarettes smoked in $(a)-(f)$ tallied with what he or she regarded as his or her daily consumption on a working day.

Questions were asked about what time he (or she) usually rose in the morning, arrived at work, had coffee, lunch and tea breaks, and departed from work; the time of going to bed was not asked, and was assumed to be eight hours before rising the next day. One reminder was sent to those who did not respond to the first inquiry. Results are presented in terms of daily events rather than actual times, although the results are similar by either method.

\section{Results}

Questionnaires were returned by 3174 (87.9\%) of the 3612 people to whom they were sent. Replies from 200 of the smokers (mainly in Group 1 on shifts with changeable hours) were excluded from the detailed analyses in Tables $2-4$ because they did? not, for example, have a morning break. In these cases, it was obviously not possible to subdivide cigarettes smoked between arrival at work and lunch into the two periods represented by categories (b) and (c) in the questionnaire. Table 1 shows the numbers and percentages of non-smokers and smokers among all those who returned questionnaires, including the 200 omitted from the analyses in Tables 2-4. Table 1 also gives, for the 904 current cigarette smokers available for analysis, excluding the 200 , the numbers of 'light' (up to 15 cigarettes a day) and 'heavy' (16 or more

Table 1 Distributions of non-smokers and smokers, and average daily cigarette consumption among smokers

\begin{tabular}{|c|c|c|c|c|c|c|c|c|c|c|c|c|c|}
\hline \multirow{3}{*}{$\begin{array}{l}\text { Smoking } \\
\text { restrictions }\end{array}$} & \multirow{3}{*}{ Group } & \multirow{3}{*}{ Sex } & \multicolumn{6}{|c|}{ Smoking habits* } & \multicolumn{2}{|c|}{ No. of smokerst } & \multirow{2}{*}{\multicolumn{2}{|c|}{$\begin{array}{l}\text { Mean no. of } \\
\text { cigarettes a dayt }\end{array}$}} & \multirow{3}{*}{ Total } \\
\hline & & & \multicolumn{2}{|l|}{ Non } & \multicolumn{2}{|l|}{ Light } & \multicolumn{2}{|c|}{ Heavy } & \multirow[t]{2}{*}{ Light } & \multirow[t]{2}{*}{ Heavy } & & & \\
\hline & & & No. & $\%$ & No. & $\%$ & No. & $\%$ & & & $\overline{L i g h t}$ & Heavy & \\
\hline Yes & 1 & $\begin{array}{l}\text { Male } \\
\text { Female }\end{array}$ & $\begin{array}{l}487 \\
253\end{array}$ & $\begin{array}{l}53 \\
59\end{array}$ & $\begin{array}{l}258 \\
114\end{array}$ & $\begin{array}{l}28 \\
27\end{array}$ & $\begin{array}{r}177 \\
62\end{array}$ & $\begin{array}{l}19 \\
14\end{array}$ & $\begin{array}{r}212 \\
84\end{array}$ & $\begin{array}{r}147 \\
38\end{array}$ & $\begin{array}{l}10 \cdot 6 \\
10 \cdot 2\end{array}$ & $22 \cdot 5$ & $\begin{array}{l}15 \cdot 5 \\
13 \cdot 5\end{array}$ \\
\hline Yes & 2 & $\begin{array}{l}\text { Male } \\
\text { Female }\end{array}$ & $\begin{array}{l}323 \\
288\end{array}$ & $\begin{array}{l}72 \\
68\end{array}$ & $\begin{array}{l}65 \\
92\end{array}$ & $\begin{array}{l}14 \\
22\end{array}$ & $\begin{array}{l}63 \\
40\end{array}$ & $\begin{array}{l}14 \\
10\end{array}$ & $\begin{array}{l}63 \\
56\end{array}$ & $\begin{array}{l}60 \\
28\end{array}$ & $\begin{array}{l}8 \cdot 6 \\
9 \cdot 3\end{array}$ & $\begin{array}{l}22 \cdot 9 \\
20 \cdot 7\end{array}$ & $\begin{array}{l}15 \cdot 6 \\
13 \cdot 1\end{array}$ \\
\hline No & 3 & $\begin{array}{l}\text { Male } \\
\text { Female }\end{array}$ & $\begin{array}{l}408 \\
311\end{array}$ & $\begin{array}{l}73 \\
78\end{array}$ & $\begin{array}{l}56 \\
45\end{array}$ & $\begin{array}{l}10 \\
11\end{array}$ & $\begin{array}{l}91 \\
41\end{array}$ & $\begin{array}{l}16 \\
10\end{array}$ & $\begin{array}{l}50 \\
\mathbf{3 5}\end{array}$ & $\begin{array}{l}89 \\
42\end{array}$ & $\begin{array}{r}9 \cdot 4 \\
10 \cdot 2\end{array}$ & $\begin{array}{l}23 \cdot 9 \\
25 \cdot 2\end{array}$ & $\begin{array}{l}18 \cdot 7 \\
18 \cdot 4\end{array}$ \\
\hline Total & & & 2070 & 65 & 630 & 20 & 474 & 15 & \multicolumn{4}{|c|}{$50055 \% 40445 \%$} & \\
\hline
\end{tabular}

Light : $₹ 15$ cigarettes a day.

Heavy: $>15$ cigarettes a day.

*Including 200 employees who gave incomplete details.

†Excluding 200 employees who gave incomplete details. 
cigarettes a day) smokers, and mean daily cigarette consumption, by sex, for each of the three groups.

The remaining results deal only with the 904 current smokers for whom complete information on smoking by time of day was available.

Table 1 shows that men recorded slightly higher daily average consumption than women. Men and women cigarette smokers in Group 3 recorded somewhat higher consumption than men and women in Groups 2 and 3.

Table 2 shows the 'average' times (to the nearest five minutes) at which members of the three groups who smoked rose, arrived at work, etc. Overtime largely accounts for the similarity in departure times, despite the earlier rising and arrival times, for those in Group 1.

Table 3 shows the average number of cigarettes an hour smoked during each of the six periods of the day for men and women according to level of smoking (light or heavy). The maximum hourly rate was generally about three times the minimum rate. In Groups 1 and 2 , the maximum rate was consistently during period $(f)$, when it was nearly $50 \%$ greater than the average rate for the whole day. Except for women who were light smokers in Group 2, the second highest rate for Groups 1 and 2 was consistently during period $(a)$. In contrast, the maximum rate in Group 3 was during the afternoon, while still at work, when it was about $30 \%$ greater than the average rate for the whole day. The second highest hourly rate also occurred at work and the lowest rate was consistently during the interval between rising and arrival at work; the rate between departure from work and going to bed was very similar to the rate for the day as a whole.

Table 4 shows the percentages of total daily cigarettes smoked by each of the three groups according to the times of day when Groups 1 and 2

Table 2 'Average' times of daily events in cigarette smokers

\begin{tabular}{|c|c|c|c|c|c|c|c|}
\hline \multirow{2}{*}{ Group } & \multirow{2}{*}{ Sex } & \multirow{2}{*}{ Rising } & \multirow{2}{*}{$\begin{array}{l}\text { Arrival } \\
\text { at work }\end{array}$} & \multicolumn{3}{|c|}{ End of breaks } & \multirow{2}{*}{$\begin{array}{l}\text { Departure } \\
\text { from work }\end{array}$} \\
\hline & & & & $\underset{\text { break }}{\text { Morning }}$ & $\underset{\text { break }}{\text { Lunch }}$ & $\begin{array}{l}\text { Afternoon } \\
\text { break }\end{array}$ & \\
\hline 1 & $\begin{array}{l}\text { Male } \\
\text { Female }\end{array}$ & $\begin{array}{l}06.00 \\
06.15\end{array}$ & $\begin{array}{l}07.30 \\
08.09\end{array}$ & $\begin{array}{l}10.20 \\
10.12\end{array}$ & $\begin{array}{l}13.35 \\
13.30\end{array}$ & $\begin{array}{l}15.35 \\
15.15\end{array}$ & $\begin{array}{l}17.00 \\
16.30\end{array}$ \\
\hline 2 & $\begin{array}{l}\text { Male } \\
\text { Female }\end{array}$ & $\begin{array}{l}07.00 \\
06.50\end{array}$ & $\begin{array}{l}08.30 \\
09.00\end{array}$ & $\begin{array}{l}10.30 \\
10.30\end{array}$ & $\begin{array}{l}13.20 \\
13.20\end{array}$ & $\begin{array}{l}15.35 \\
15.25\end{array}$ & $\begin{array}{l}17.10 \\
16.00\end{array}$ \\
\hline 3 & $\begin{array}{l}\text { Male } \\
\text { Female }\end{array}$ & $\begin{array}{l}07.00 \\
07.05\end{array}$ & $\begin{array}{l}08.30 \\
08.40\end{array}$ & $\begin{array}{l}11.00 \\
10.20\end{array}$ & $\begin{array}{l}13.35 \\
13.35\end{array}$ & $\begin{array}{l}15.15 \\
15.10\end{array}$ & $\begin{array}{l}16.50 \\
16.45\end{array}$ \\
\hline
\end{tabular}

Times given to nearest five minutes.

Table 3 Smoking rate (cigarettes an hour) during different periods of the day by men and women, by level of smoking

\begin{tabular}{|c|c|c|c|c|c|c|c|}
\hline \multirow{3}{*}{ Period of day* } & \multirow{3}{*}{$\begin{array}{l}\text { Level of } \\
\text { smoking }\end{array}$} & \multicolumn{4}{|c|}{ Smoking restrictions } & \multirow{2}{*}{\multicolumn{2}{|c|}{$\begin{array}{l}\text { Without restrictions } \\
\text { Group } 3 \\
\text { Office work }\end{array}$}} \\
\hline & & \multicolumn{2}{|c|}{$\begin{array}{l}\text { Group } 1 \\
\text { Production work }\end{array}$} & \multicolumn{2}{|l|}{$\begin{array}{l}\text { Group } 2 \\
\text { Office work }\end{array}$} & & \\
\hline & & Men & Women & Men & Women & Men & Women \\
\hline (a) Rising/arrival at work & $\begin{array}{l}\text { Light } \\
\text { Heavy }\end{array}$ & $\begin{array}{ll}0.77 & (1 \cdot 0) \\
1.63 & (2 \cdot 2)\end{array}$ & $\begin{array}{ll}0.68 & (1 \cdot 1) \\
1.61 & (2 \cdot 4)\end{array}$ & $\begin{array}{ll}0.48 & (0.8) \\
1.46 & (2.3)\end{array}$ & $\begin{array}{ll}0.33 & (0.6) \\
1.49(2.7)\end{array}$ & $\begin{array}{ll}0.44 & (0.4) \\
1.14 & (1.7)\end{array}$ & $\begin{array}{l}0 \cdot 21 \quad(0 \cdot 8) \\
1 \cdot 10(1 \cdot 7)\end{array}$ \\
\hline (b) Arrival at work/morning break & $\begin{array}{l}\text { Light } \\
\text { Heavy }\end{array}$ & $\begin{array}{l}0.47 \quad(1.4) \\
0.84 \quad(2.5)\end{array}$ & $\begin{array}{ll}0.49 & (1 \cdot 2) \\
0.91 & (2 \cdot 3)\end{array}$ & $\begin{array}{ll}0.39 & (0 \cdot 8) \\
1.27 & (2 \cdot 6)\end{array}$ & $\begin{array}{ll}0.55 & (1 \cdot 0) \\
0.92 & (1.8)\end{array}$ & $\begin{array}{l}0 \cdot 72(1 \cdot 1) \\
1.94(3 \cdot 1)\end{array}$ & $\begin{array}{ll}0.69 & (1 \cdot 3) \\
1.87 & (3.4)\end{array}$ \\
\hline (c) Morning break/lunch & $\begin{array}{l}\text { Light } \\
\text { Heavy }\end{array}$ & $\begin{array}{ll}0.52 & (1 \cdot 7) \\
0.92 & (3.0)\end{array}$ & $\begin{array}{ll}0.46 & (1 \cdot 5) \\
0.76 & (2 \cdot 5)\end{array}$ & $\begin{array}{ll}0.43 & (1 \cdot 3) \\
1 \cdot 10 & (3 \cdot 3)\end{array}$ & $\begin{array}{ll}0.45 & (1 \cdot 3) \\
0.92 & (2 \cdot 7)\end{array}$ & $\begin{array}{ll}0 \cdot 49 & (1 \cdot 6) \\
1 \cdot 33 & (4 \cdot 2)\end{array}$ & $\begin{array}{l}0.49(1 \cdot 7) \\
1 \cdot 30(4 \cdot 4)\end{array}$ \\
\hline (d) Lunch/afternoon break & $\begin{array}{l}\text { Light } \\
\text { Heavy }\end{array}$ & $\begin{array}{ll}0 \cdot 63 & (1 \cdot 2) \\
1 \cdot 14 & (2 \cdot 1)\end{array}$ & $\begin{array}{ll}0.59 & (1 \cdot 1) \\
0.96 & (1 \cdot 7)\end{array}$ & $\begin{array}{l}0.44 \quad(0.9) \\
1.16 \quad(2.3)\end{array}$ & $\begin{array}{l}0.44(0.9) \\
0.87(1 \cdot 7)\end{array}$ & $\begin{array}{ll}0.76 & (1 \cdot 4) \\
2 \cdot 00 & (3 \cdot 0)\end{array}$ & $\begin{array}{ll}0.79 & (1 \cdot 2) \\
1 \cdot 73 & (3 \cdot 3)\end{array}$ \\
\hline (e) Afternoon break/departure & $\begin{array}{l}\text { Light } \\
\text { Heavy }\end{array}$ & $\begin{array}{l}0.36(0.6) \\
0.96(1.7)\end{array}$ & $\begin{array}{ll}0.25 & (0.4) \\
0.40 & (0.6)\end{array}$ & $\begin{array}{ll}0 \cdot 34 & (0 \cdot 6) \\
1 \cdot 18 \quad(2 \cdot 0)\end{array}$ & $\begin{array}{ll}0 \cdot 08 & (0 \cdot 1) \\
0 \cdot 71 & (1 \cdot 1)\end{array}$ & $\begin{array}{ll}0 \cdot 69 & (1 \cdot 2) \\
2 \cdot 15 & (3 \cdot 3)\end{array}$ & $\begin{array}{ll}0 \cdot 86 & (1 \cdot 2) \\
2 \cdot 21 & (3 \cdot 3)\end{array}$ \\
\hline (f) Departure from work/bed & $\begin{array}{l}\text { Light } \\
\text { Heavy }\end{array}$ & $\begin{array}{l}0.94(4 \cdot 7) \\
2 \cdot 26(11 \cdot 0)\end{array}$ & $\begin{array}{l}0.87(4 \cdot 9) \\
2 \cdot 05(11 \cdot 2)\end{array}$ & $\begin{array}{l}0.72(4 \cdot 2) \\
1.79(10 \cdot 4)\end{array}$ & $\begin{array}{l}0.90(5.4) \\
1.81(10.7)\end{array}$ & $\begin{array}{ll}0.65 & (3 \cdot 7) \\
1.44 & (8 \cdot 6)\end{array}$ & $\begin{array}{l}0.58(4 \cdot 0) \\
1 \cdot 36(9 \cdot 1)\end{array}$ \\
\hline (g) Whole day & $\begin{array}{l}\text { Light } \\
\text { Heavy }\end{array}$ & $\begin{array}{l}0.66(10 \cdot 6) \\
1.40(22 \cdot 5)\end{array}$ & $\begin{array}{l}0 \cdot 62(10 \cdot 2) \\
1 \cdot 29(20 \cdot 7)\end{array}$ & $\begin{array}{l}0.53(8 \cdot 6) \\
1.42(22.9)\end{array}$ & $\begin{array}{l}0 \cdot 58(9 \cdot 3) \\
1 \cdot 28(20 \cdot 7)\end{array}$ & $\begin{array}{l}0.62(9 \cdot 4) \\
1.57(23.9)\end{array}$ & $\begin{array}{l}0.58(10 \cdot 2) \\
1.49(25 \cdot 2)\end{array}$ \\
\hline $\begin{array}{l}\text { Ratio of maximum/minimum } \\
\text { rate }\end{array}$ & $\begin{array}{l}\text { Light } \\
\text { Heavy }\end{array}$ & $\begin{array}{l}2 \cdot 6 \\
2 \cdot 7\end{array}$ & $\begin{array}{l}3 \cdot 5 \\
5 \cdot 1\end{array}$ & $\begin{array}{l}2 \cdot 1 \\
1 \cdot 6\end{array}$ & $\begin{array}{r}11 \cdot 3 \\
2 \cdot 5\end{array}$ & $\begin{array}{l}1 \cdot 7 \\
1 \cdot 9\end{array}$ & $\begin{array}{l}4 \cdot 1 \\
2 \cdot 0\end{array}$ \\
\hline $\begin{array}{l}\text { Ratio of rate after work to rate for } \\
\text { whole day }[(\mathrm{f}) /(\mathrm{a}) \text { to (f)] }\end{array}$ & $\begin{array}{l}\text { Light } \\
\text { Heavy }\end{array}$ & $\begin{array}{l}1.42 \\
1.61\end{array}$ & $\begin{array}{l}1 \cdot 40 \\
1 \cdot 59\end{array}$ & $\begin{array}{l}1 \cdot 36 \\
1 \cdot 26\end{array}$ & $\begin{array}{l}1 \cdot 55 \\
1.41\end{array}$ & $\begin{array}{l}1 \cdot 05 \\
0.92\end{array}$ & $\begin{array}{l}1 \cdot 00 \\
0.91\end{array}$ \\
\hline
\end{tabular}

*For precise definitions, see text.

Figures in brackets are average numbers of cigarettes smoked. 
were not restricted (from rising until arrival at work, and from departure from work until going to bed) and for the periods when they were restricted. Members of Groups 1 and 2 consumed about $40 \%$ of their total daily cigarettes during restricted periods (the figures for women being slightly lower than those for men); by comparison, those in Group 3 smoked more than half their daily total during the same periods.

\section{Discussion}

It is possible that the presence or absence of smoking restrictions might have influenced answers to the questionnaire. For example, Groups 1 and 2 might have felt obliged to record proportionately more of their consumption in unrestricted periods of the day than was actually the case, and their total daily consumption may also have appeared less than it really was (and less than Group 3) for reasons connected with the presence of smoking restrictions. However, the inquiry was strictly confidential and there was no evidence that anxiety about the possible detection and reporting of infringements of smoking restrictions influenced the answers given.

Secondly, cigarette consumption is likely to be under-reported in studies on smoking habits. The rates in Table 3 therefore probably underestimate the real figures. However, the main objective was to compare rates within and between various subgroups, so that unless the extent of underreporting varied considerably from one subgroup to another, this difficulty was probably not important.

Thirdly, a few smokers in Groups 1 and 2 may have chosen occupations which had smoking restrictions because they felt it might help them to limit their cigarette consumption. Conversely, some of those in Group 3 may have chosen their place of work because of the absence of restrictions. We have no way of knowing to what extent either of these possibilities occurred.

Table 3 shows that there is usually not less than a twofold difference between the highest and lowest hourly smoking rate for the various periods of the day. In two subgroups, the difference is more than fivefold, although the ratios shown are subject to wide confidence intervals. On average, however, the difference for all smokers is nearly threefold, and this may clearly be relevant when taking specimens for $\mathrm{COHb}$ analyses. The variation in rates is more marked in women than men, especially in Groups 1 and 2. The times of the maximum smoking rates appear to vary according to whether smoking restrictions are in force or not; where they are, these rates occur consistently between departure from work and going to bed, while in their absence, they tend to occur while still at work. The production nature of the jobs in which most of the members of Group 1 were engaged almost certainly made it more difficult for them to smoke at work than those in Group 2 and, to an even greater extent, Group 3. It is therefore interesting that after work, the average consumption by Group 1 was about $50 \%$ higher than for the whole day, whereas for Group 2 the increase of $40 \%$ wase rather less; in Group 3 the rate after work waso almost identical with the rate for the day as a whole. The presence or absence of smoking restrictions at work may thus be an important determinant of smoking patterns during the day, although other explanations for the differences are possible. The differences in total daily consumption between men and women in Group 3, and those in Groups 1 and 2, are not very large and are certainly not as striking as the differences in patterns already referred to. It is obviously possible that restrictions on smoking at work may influence total daily consumption, but our data provide no clear evidence on this.

Table 4 Percentages of total daily cigarettes smoked during specified periods of the day

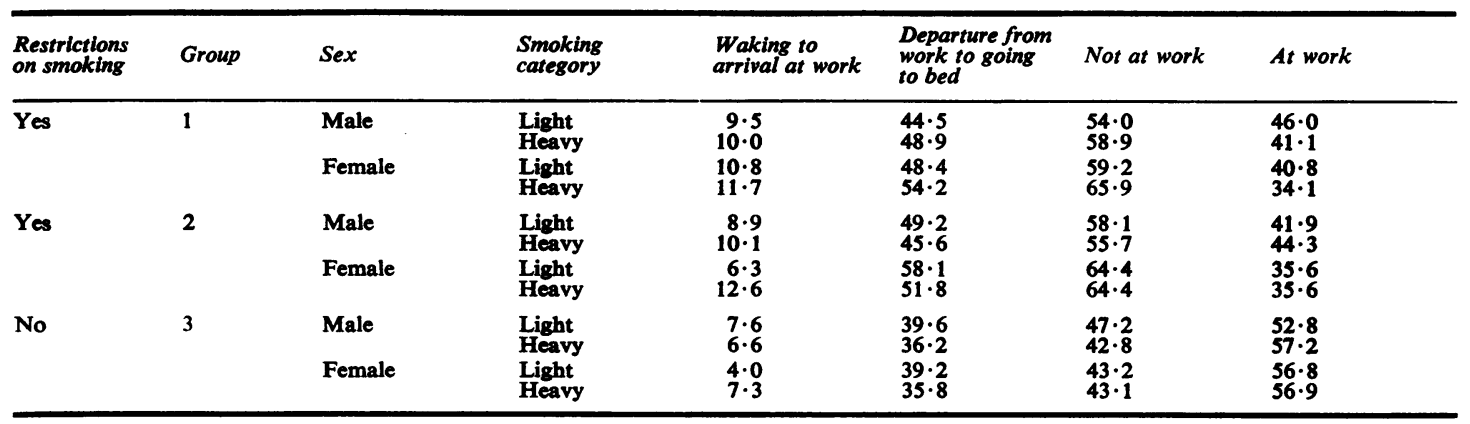


On the assumption that the groups in this survey are representative of other groups, and from knowledge of the validity of a single $\mathrm{COHb}$ estimation as a measure of the total daily carbon monoxide uptake from smoking (Wald et al., 1975), our results will help in deciding the time of day at which blood for COHb should be taken. Clearly, the optimum time will generally be as late in the day as possible, but this will often be difficult for both the investigators and participants in many studies.

We wish to thank all those who took part in the study for their help.

Reprints from T. W. Meade, MRC-DHSS Epidemiology and Medical Care Unit, Northwick Park Hospital, Harrow, Middlesex HA1 3UJ.
References

Astrup, P. (1972). Some physiological and pathological effects of moderate carbon monoxide exposure. British Medical Journal, 4, 447-452.

Wald, N., and Howard, S. (1975). Variation in carboxyhaemoglobin levels in smokers. British Medical Journal, $1,393$.

Wald, N., Howard, S., Smith, P. G., and Bailey, A. (1975). Use of carboxyhaemoglobin levels to predict the development of diseases associated with cigarette smoking. Thorax, 30, 133-139.

Wald, N., Howard, S., Smith, P. G., and Kjeldsen, K. (1973). Association between atherosclerotic diseases and carboxyhaemoglobin levels in tobacco smokers. British Medical Journal, 1, 761-765. 